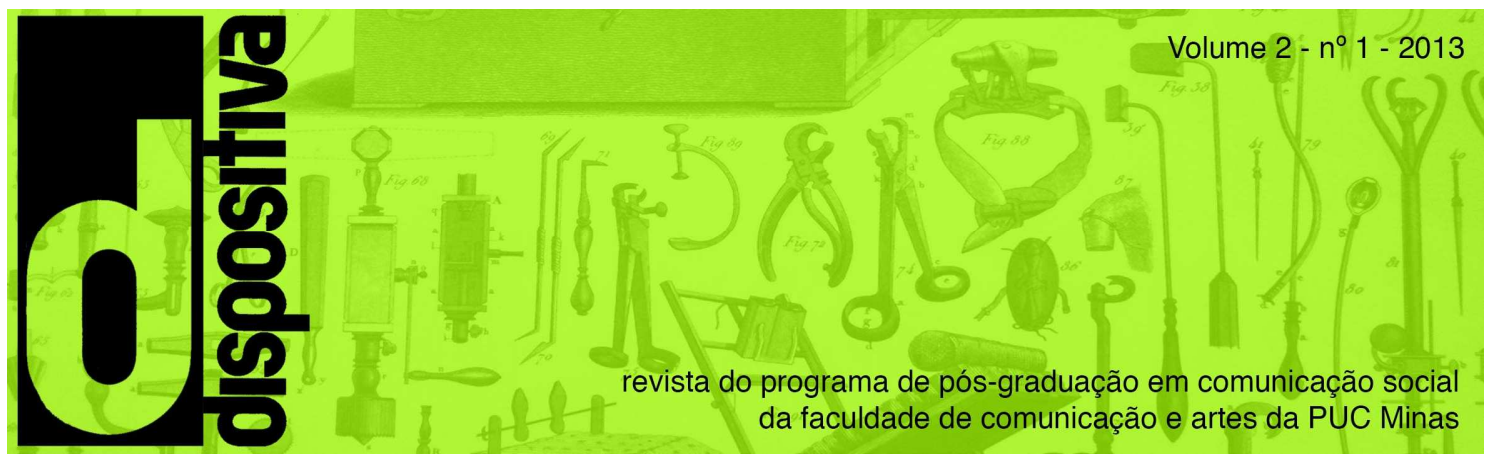

Palavra

\title{
Bios midiático // The media Bios
}

Muniz Sodré ${ }^{1}$

O bios midiático é uma espécie de clave virtual aplicada à vida cotidiana, à existência real-histórica do indivíduo. Em termos de puro livre-arbítrio, pode-se entrar e sair dele, mas nas condições civilizatórias em que vivemos (urbanização intensiva, relações sóciomercadológicas, predomínio do valor de troca capitalista), estamos imersos na virtualidade midiática, o que nos outorga uma forma de vida vicária, paralela, "alterada" pela intensificação da tecnologia audiovisual conjugada ao mercado. Isto faz do bios midiático a indistinção entre tela e realidade - realidade "tradicional", bem entendido, uma vez que a realidade de hoje já se constitui sob a égide da integralidade espetacularizada ou imagística a que aspira o virtual. Trata-se de uma inflexão exacerbada do imaginário que, como bem o viu Deleuze, "não é o irreal, mas a indiscernibilidade do real e do irreal" ${ }^{2}$.

Esse bios não se define radicalmente, entretanto, como soma de todas as imagens tecnicamente produzidas, e sim como o poder dos modelos (assim como na ordem mítica, o poder é dos símbolos primordiais ou dos arquétipos), que se atualizam ou se concretizam em determinados tipos de imagens, historicamente sobredeterminadas. As imagens midiáticas que regem as relações sociais provêm dos modelos hegemônicos do capital e do mercado globais.

O espetáculo de hoje resulta, assim, de uma sobredeterminação histórica da imagem. A espetacularização é, na prática, a vida transformada em sensação ou em

\footnotetext{
${ }^{1}$ Graduado em Direito pela UFBA (1964), mestre em Sociologia da Informação e Comunicação pela Université de Paris IV (Paris-Sorbonne) (1967) e doutor em Letras pela UFRJ (1978). Atualmente é Professor Emérito da UFRJ. Possui cerca de 30 livros publicados nas áreas de Comunicação e Cultura. ${ }^{2}$ Deleuze, Gilles. Pourparlers. Minuit, 1990, p. 93.
} 
entretenimento, com uma economia poderosa voltada para a produção e consumo de filmes, programas televisivos, música popular, parques temáticos, jogos eletrônicos. Efeitos de fascinação, moda, celebridade e emoção a todo custo permeiam sistematicamente essa forma de vida emergente, em que a estesia detém o primado sobre velhos valores de natureza ética. O fenômeno estético toma-se insumo para a estimulação da vida, doravante dirigida para a indústria e o mercado. É, portanto, mais aisthesis do que ethos - embora se possa falar de um ethos da estética, ou seja, de uma inteligibilidade do sensível capaz de levar a uma "ética" ou uma arquitetura social de valores.

É verdade que os modelos geradores de imagens são logicamente inteligíveis. Na prática, porém, trata-se de um real semiurgicamente constituído em toda a sua extensão, uma verdadeira cultura das sensações e emoções, da qual se faz uma experiência mais afetiva do que lógico-argumentativa. Daí a prevalência dos estereótipos, que são emoções coletivas esteticamente condensadas, nos territórios imateriais do bios midiático. Realiza-se uma espécie de "ação estética" industrial, extensiva à vida social como um todo, o que não deixa de lembrar a concepção do pragmatista norte-americano John Dewey sobre a ação estética como interação da forma com o real histórico, assim como circulação de reflexos e sensações ${ }^{3}$. Ao mesmo tempo, porém, vale atentar para a sua advertência no sentido de que tal experiência pode deformar-se por acúmulo de fantasias e por falta de reelaboração afetiva do vivido.

Pode-se levantar aqui a questão de se saber se o novo bios ainda está ancorado no plano da representação. São vários os teóricos da chamada "realidade virtual" que consideram estar ultrapassada a lógica da representação, uma vez que o objeto duplicado em imagens sintéticas pelas novas tecnologias da informação - na realidade, "recriado" a partir de suas características internas e de suas regras de ação, portanto, a partir de seu modelo de construção, e não de sua forma fechada - induz a uma nova experiência perceptiva, independente de qualquer realidade prévia. Certamente não se trata mais da representação que tem por trás o real fenomênico ou uma identidade forte, social ou individual, ancorada na história, o que autoriza falar em superação da lógica tradicional das reproduções icônicas. De fato, todo esse sistema de representações sem

\footnotetext{
${ }^{3}$ Cf. Dewey, John. Art as experience, 1934.
} 
referentes, tomadas puros modelos-imagens, digitalizadas e táteis, parece pertencer a uma dimensão aquém da representacional. 